\title{
Impacts of the COVID-19 pandemic on ginger production: Supply chains, labor, and food security in Northeast Thailand
}

\author{
Pakhuan Wannaprasert ${ }^{1}$, Sukanlaya Choenkwan ${ }^{1, *}$ \\ 1 Department of Agricultural Extension and Agricultural Systems, Faculty of Agriculture, Khon Kaen \\ University, Khon Kaen, 40002 \\ *Corresponding author: sukanl@kku.ac.th, kun_na@hotmail.com
}

\begin{abstract}
This paper evaluates the impacts of the COVID-19 pandemic on ginger production and ginger farmer livelihoods in Loei province where ginger is an important commercial crop. The analysis also pays particular attention to the lockdown period (March - June 2020). Data for this study were obtained from several sources, including information from government records, onsite observation, and semi-structured interviews. Field research was conducted in August 2020 for 10 days in a village in Plaba sub-district. Data was obtained using an interview guide with 55 ginger farmers who have been growing ginger for at least 3 years. The results show that the lock down and transportation restrictions affected input supply chains, such as fertilizer and rhizome seeds. The flow of international labor was also constrained affecting skilled labor shortage in ginger production. However, COVID-19 shows positive impacts on ginger production systems. Ginger price is higher than the previous year because of world market demand and the belief that ginger can be used as an antioxidant to prevent COVID-19 infections. Moreover, the result also shows that these ginger farmers are somewhat resilient in the face of COVID-19 as they are not much dependent on markets for their own subsistence needs. Finally, this study recommends that promoting farmers to produce their own food and diversify commercial crops would be a good strategy for farmers to survive the crisis.
\end{abstract}

Keywords: high value crop; mountain agriculture; food security; farmer coping strategies; commercial crops,

\section{Introduction}

Ginger (Zingiber officinale) is a perennial herb revered as one of the most popular and valued spices of the world. The most useful part of this plant is the underground rhizome. Besides being used as a spice, the dry ginger is also used to produce oil, oleoresin, essences, soft drinks, and nonalcoholic beverages. Ginger also has manifold medicinal properties as a carminative and stimulation of gastro-intestinal tracts (Bc, 2019).

Ginger is an important commercial horticultural crop, and is cultivated in more than 35 countries around the world. In 2019, the global production of ginger was 4,081,374 tons. India was the top producing country accounting for $43.81 \%$ of total global production and Nigeria was second, accounting for 16.94\% (FAOSTAT, 2020b). The five leading ginger exporting countries in 2019 were China with US\$ 571.72 million (537,826 tons), Thailand (63,969 tons), Netherlands $(59,927$ tons), Nigeria (30,922 tons) and United Arab Emirates (29,370 tons) (FAOSTAT, 2020a).

Thailand was the sixth highest ginger producing country in the world amounting to 166,923 tons, and accounting for about 4.09\% of the world's total ginger production in 2019 (FAOSTAT, 2020b). Thailand was also the second leading ginger exporting country in the world with a value of US\$55.77 million (FAOSTAT, 2020a). In Thailand, ginger is mainly grown in the mountainous regions of Loei, Mae Hong Son, Chiang Rai, Phetchabun and Phitsanulok provinces. As of 2018, ginger cultivation covered about 11,809 rai (1,889.5 ha) (Department of Agriculture Extension, 2019). These figures amount to a very small proportion compared to total agricultural land (149.25 million rai, or 23.88 million ha) and total number of farmers in the country (18.024 million farmers) (Department of Agriculture Extension, 2020). Productivity of ginger in Thailand averages $3,034 \mathrm{~kg} / \mathrm{rai}(485.44 \mathrm{~kg} / \mathrm{ha})$ 
and ginger prices averaged 19.65 Baht $/ \mathrm{kg}$ (USD $0.6 / \mathrm{kg}$ ) (Department of Agriculture Extension, 2019).

Ginger farmers have long taken on risks to grow ginger, both due to its unstable price and its sensitivity to disease. Once ginger is infected, farmers will not get any yield for that year. However, in a good year, ginger generates high profit for farmers. In ginger-growing regions, farmers view the crop for its potential to boost incomes (Choenkwan, 2017). As in Wayanad district in southern India, ginger is an important commercial crop throughout the community (Münster, 2015). Nevertheless, ginger is also a "gamble." It is given rise of a class of people (known as ginger kings), who have generated extreme wealth in the space of just a few years by cultivating ginger. Meanwhile, the gamble has also been the cause of financial ruin that has driven many cultivators to suicide when the ginger price has dramatically dropped, or due to crop failures from disease. In these cases, ginger is described as a killer. However, many farmers are willing to take on the risks. Although ginger often gains attention for its potential to generate high profits for farmers, limited attention has been given to expanding production aspects for the betterment of smallholder farmers engaged in production and marketing activities. This has also been observed in southern Ethiopia, whereby ginger serves as a commercial crop and less attention has been given to the role of smallholders (Geta and Kifle, 2011).

The objectives of this study are to evaluate the impacts of the COVID-19 pandemic on this dynamic crop. The COVID-19 outbreak has rapidly disrupted economies worldwide. There is sufficient evidence to affirm that the pandemic caused by the COVID-19 disease has an important effect on agriculture and the food supply chain. Movement restrictions cause labor shortages for the harvest, or difficulties for farmers to bring their products to market (Siche, 2020). In India, border closers, quarantines, and supply chain disruptions are restricting production capabilities. Productivity is also threatened by emerging shortages of agricultural labor that disrupt planting, harvests, and other farming operations (Balwinder-Singh et al., 2020). Joshi et al. (2019) reports that emergence of the COVID-19 pandemic in March 2020 had negative impacts in the postharvest supply chain, transportation, retail marketing and trade of fruits and vegetables. The COVID-19 lockdown impacts on agriculture in Uttar Pradesh, India has seriously disrupted Indian farms (Kumar et al., 2021). Farms have been less profitable amid rising food prices, putting pressure on food security. Moreover, a lack of migrant labor has led to a loss of produce and affected the crop harvest. In Eastern and Southern Africa, COVID-19 impacted bean value chains and found that government restrictions influenced the availability and cost of farm inputs and labors, distribution, and consumption of beans (Nchanji et al., 2021). South Asia's food production systems have also been similarly disrupted by COVID-19 (Amjath-Babu et al., 2020). International and domestic supply chains for fertilizers, agro-chemicals, machinery, and seeds have been impeded by import and movement restrictions. In addition to production disruptions, farmers also face output market challenges, with fewer buyers willing to purchase products, particularly for perishables. Commodities with high income elasticities such as fruits and vegetables, meat, fish, milk, and eggs are facing significant declines in demand due to contraction in incomes of non-salaried informal workers and price spikes, especially in urban areas (Abhishek et al. 2020).

In March to June 2020, Thailand introduced restrictions to the movement of people and goods. These measures helped to stem the spread of COVID-19 but are having widespread effects to all household groups. Decreasing economic activity caused some employees to be laid off or reduced their salary. Self-employed households lost their income from lower demand, and households that rely on remittances are also affecting rural economies (Tungkanjanapas and Chotiwattanakun, 2020). The Asia-Pacific Farmers Program (2020) indicated that there are around 700,000 workers who are out of work due to the implemented measures to contain COVID-19. Local Act (2020), an organization that conducted a survey to highlight challenges faced by Thai farmers during the COVID-19 outbreak found that most farmers faced marketing problems, low prices of their products, and decreasing incomes. During COVID-19, both domestic and export markets were shut down. In 
addition, the distribution channels of products from farmers to long-distance consumers were disrupted and delayed because of the announcement of an Emergency decree prohibiting travel across the province at night. Moreover, some farmers provided delivery service to their consumers, which they had to stop because of the need to comply with government mobility policies requesting people to refrain from crossing provinces.

This study took place in a village in Phu Ruea district, Loei province of Thailand, which has continuously grown ginger for more than 30 years. This study presents results from field surveys including demographic characteristics of informants, ginger cultivation practices, and situates the data in the context of impacts of COVID-19, examining the changes in ginger production and coping strategies of ginger farmer households and their livelihoods.

\section{Methodology}

\subsection{Conceptual Framework}

The flow chart in Figure 1 hypothesizes the direct and indirect pathways of COVID-19 impacts on ginger production systems and ginger farmer households.

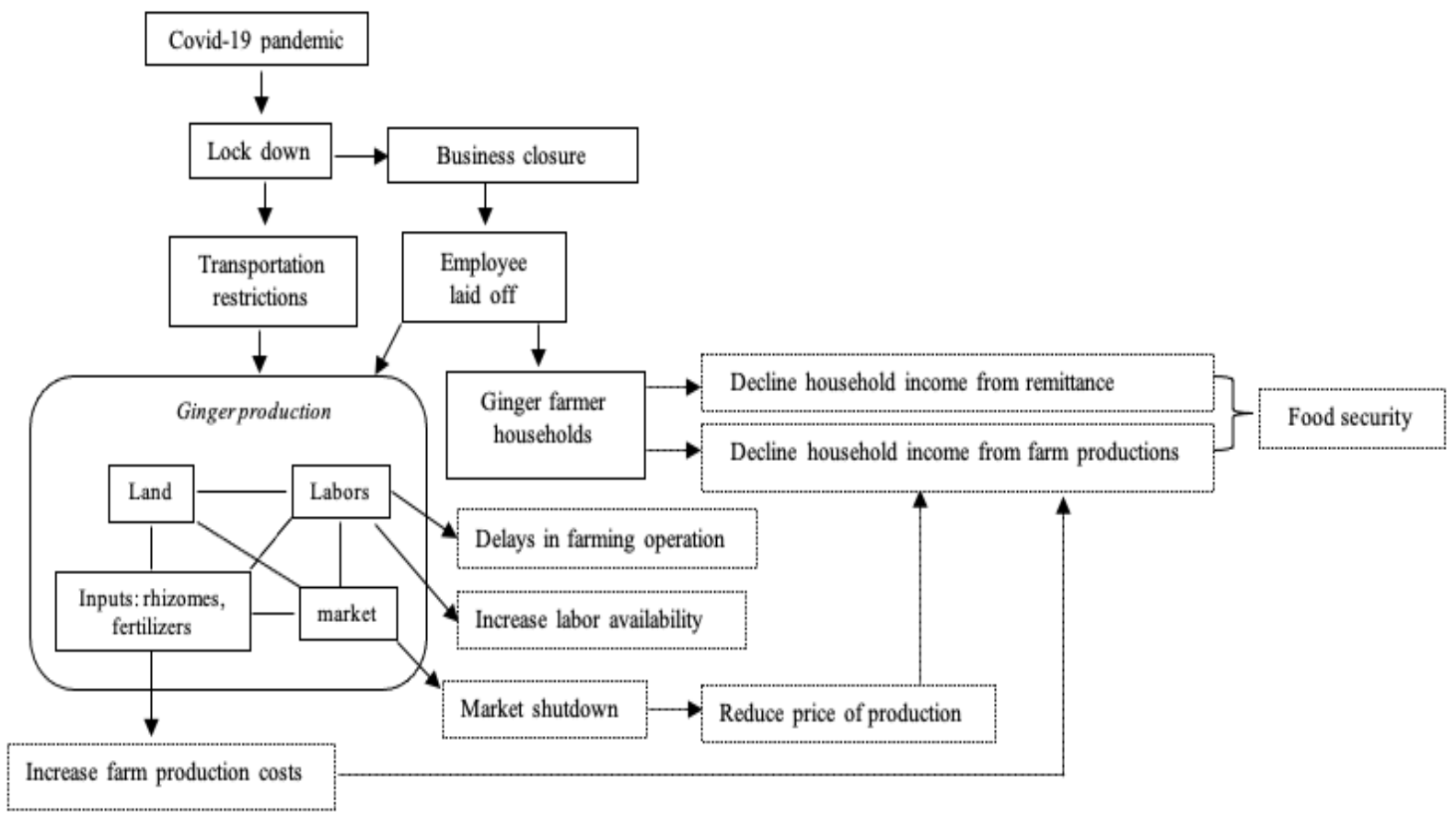

Figure 1. Flow chart of potential COVID-19 impact pathways that may affect ginger production systems and ginger farmers households

\subsection{Study site}

This research was conducted in Plaba sub-district (Map 1), Phu Ruea district, Loei province in the northeastern region of Thailand. Plaba sub-district is located in the mountainous area with an elevation about 800-900 meters above mean sea level and is the highest elevations that people live in the Northeast (Choenkwan et al., 2014) (Figure 2)

The sub-district covers about $33,908 \mathrm{rai}^{1}(5,425.3 \mathrm{ha})$ which is comprised of 23,121 rai $(3,699.4$ ha) of agricultural land or about $68 \%$ of the total area. The rest of the land uses are forest, settlement area, and water resources (Plaba Tambon Administrative Organization, 2019). This sub-district is

11 ha $=6.25$ rai 
surrounded by forests. About $90 \%$ of total sub-district's area is under protected area status (Office of Soil Resource Survey and Research, 2008). Agriculture is the main economic activity.
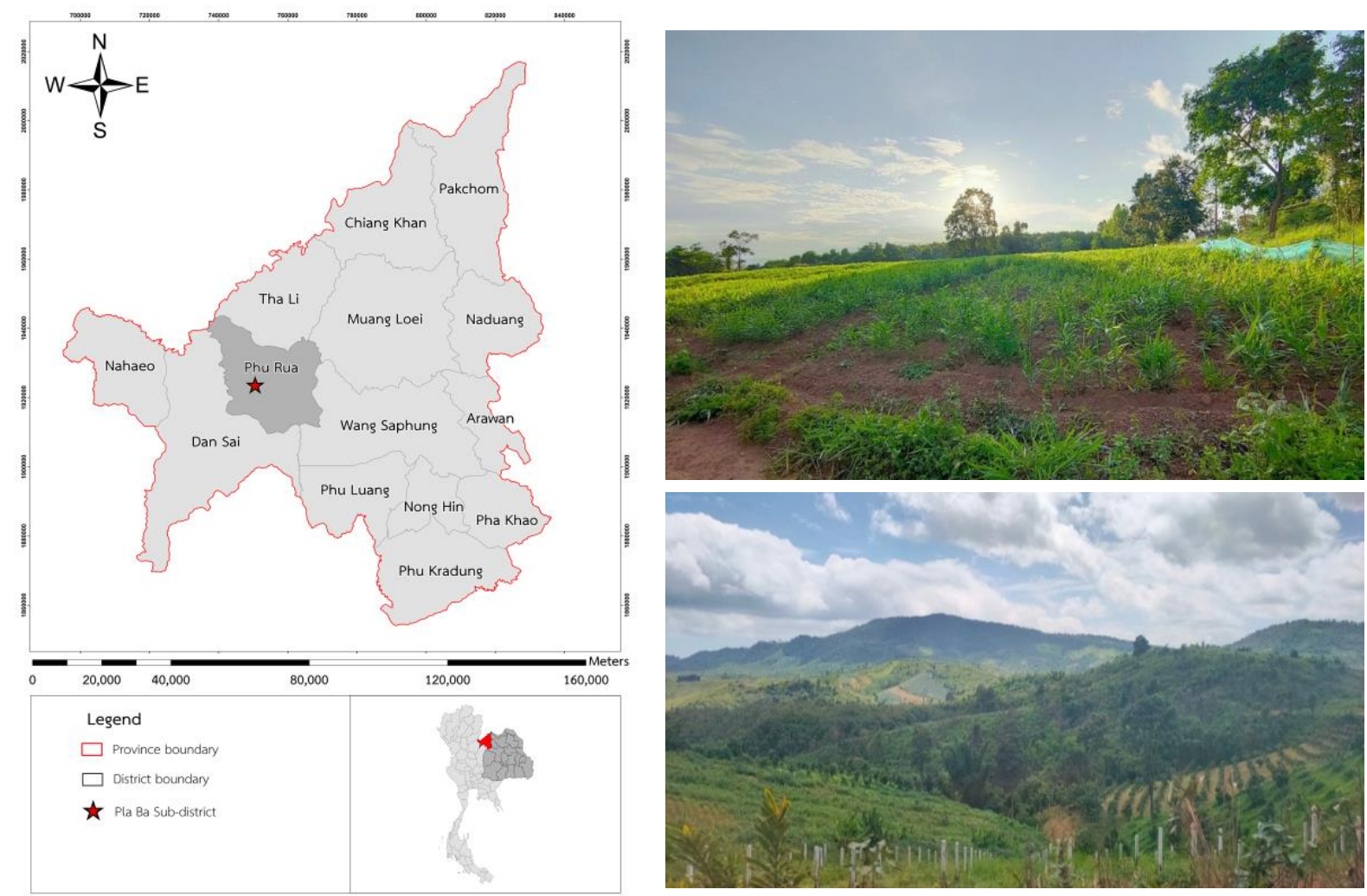

Figure 2. Map and Landscape of the study site

\subsection{Data collection and Analysis}

Data for this study were obtained from several sources, including information from government records and offices, onsite observation, and semi-structured interviews. Field research was conducted in the sub-district in August 2020 for 10 days to investigate how COVID-19 affected ginger production and ginger cultivator households. Detailed information on individual farms were collected using an interview guide and engaged with ginger farmers in Plaba village where the highest number of ginger farmers are located in the sub-district (Plaba Tambon Administrative Organization, 2019). According to records of the Plaba Tambon Administrative Organization (2019), there are 180 households growing ginger in this village. This study aims to collect data on at least $30 \%$ of these farmers, and a total of 55 ginger farmers were surveyed. Snowball sampling was employed. Farmers were selected based on two main criteria: 1) they have been growing ginger for at least three years; and, 2) they are available and willing to answer our questions. The purpose of the study was explained to the farmers and they were asked for their consent to provide information, in which all farmers verbally gave their consent. The researchers visited each household for the interview. Face-to-face interviews were conducted in strict adherence to the COVID-19 health and safety measures including maintaining social distance, mask-wearing, and hand washing. The interviews consisted of informal conversations with questions about their demographic characteristics, ginger production practices, impacts of COVID-19 on ginger production, and their household coping strategies on impacts of COVID-19. Interviews varied in length from 45-60 minutes. Descriptive statistics were used to analyze data. Regarding the prevention of spread of COVID-19, social distancing practices were applied during the interview. 


\section{Results}

\subsection{Demographic characteristics of informants}

Table 1 shows that the average age of the informants was 47.9 years old and $70.9 \%$ of them were within the age bracket of between $41-60$ years old. More than half (54.5\%) were male. Average labor was about 2.7 people per household. The average land holding per household was 73.5 rai (11.8 ha) with land title of Por. Bor. Tor. 5, which is evidence that the occupier of a plot of land has been issued a tax number and has paid taxes for using the benefit of the land. This confers no ownership rights but was formerly used to establish that the holder was occupying a plot of land (Thailand law online, 2016). Farmers practice several agricultural activities, including rice (both hill rice and wet rice), ginger, maize, cassava, fruit orchard, dragon fruit, rubber, and vegetables (Table 2). These farmers have been growing ginger for several years, with an average of 18 years, the longest one of 35 years, and shortest one of 3 years. Income from ginger covers a large share of total household income, which was about $54.8 \%$ in average. Approximately $58.2 \%$ of farmers earned income from ginger accounting for anywhere between $50-70 \%$ of the total share of their household income.

Table 1. Distribution of informants according to their social and economic characteristics $(n=55)$

\begin{tabular}{|c|c|c|}
\hline Characteristics & Frequency & Percentage \\
\hline \multicolumn{3}{|l|}{ Sex } \\
\hline male & 30 & 54.5 \\
\hline female & 25 & 45.5 \\
\hline \multicolumn{3}{|l|}{ Age (years) } \\
\hline 40 and below & 12 & 21.8 \\
\hline $41-60$ & 39 & 70.9 \\
\hline 61 and above & 4 & 7.3 \\
\hline \multicolumn{3}{|l|}{$\min 29, \max 65$, mean 47.87, S.D. 9.432} \\
\hline \multicolumn{3}{|l|}{ Household farm labors (persons) } \\
\hline None & 6 & 10.9 \\
\hline $1-2$ & 29 & 52.7 \\
\hline $3-4$ & 14 & 25.5 \\
\hline more than 4 & 6 & 10.9 \\
\hline \multicolumn{3}{|l|}{$\min 1, \max 7$, mean 2.69, S.D. 1.446} \\
\hline \multicolumn{3}{|l|}{ Land holding (rai) } \\
\hline 50 and less than & 20 & 36.4 \\
\hline $51-100$ & 27 & 49.1 \\
\hline more than 100 & 8 & 14.5 \\
\hline \multicolumn{3}{|l|}{$\min 22, \max 200$, mean 73.53, S.D. 38.804} \\
\hline \multicolumn{3}{|l|}{ Total household income in 2019 (Baht) } \\
\hline 100,000 and less than & 15 & 27.3 \\
\hline $100,001-500,000$ & 33 & 60.0 \\
\hline more than 500,000 & 7 & 12.7 \\
\hline \multicolumn{3}{|l|}{$\min 60,000, \max 1,000,000$, mean 260,454, S.D. $221,965.69$} \\
\hline \multicolumn{3}{|l|}{ Share of income from ginger cultivation to total household income } \\
\hline less than 50 & 32 & 58.2 \\
\hline $50-70$ & 9 & 16.4 \\
\hline \multicolumn{3}{|l|}{70} \\
\hline \multicolumn{3}{|l|}{$\min 20, \max 9, \operatorname{mean} 54.78$, S.D. 17.362} \\
\hline \multicolumn{3}{|l|}{ Experiences in ginger cultivation (years) } \\
\hline 10 and less than & 13 & 23.6 \\
\hline $11-20$ & 34 & 61.8 \\
\hline more than 20 & 8 & 14.5 \\
\hline $\min 3, \max 35$, mean 18.09, S.D. 6.407 & & \\
\hline
\end{tabular}


Data source: Field survey conducted in 2020

Table 2. Distribution of informants according to their agricultural activities $(n=55)$

\begin{tabular}{lcccccc}
\hline $\begin{array}{c}\text { Agricultural } \\
\text { activities }\end{array}$ & \multirow{2}{*}{ Frequency } & Percentage & \multicolumn{4}{c}{ Farm sizes } \\
\hline Rice & 52 & 94.5 & 10.44 & 5.050 & 4.00 & 26.00 \\
Ginger & 55 & 100.0 & 8.26 & 4.740 & 2.00 & 25.00 \\
Maize & 20 & 36.4 & 18.75 & 14.882 & 2.00 & 75.00 \\
Cassava & 48 & 87.3 & 17.48 & 13.640 & 3.00 & 70.00 \\
Fruit orchards & 15 & 27.3 & 5.50 & 4.424 & 0.50 & 15.00 \\
Dragon fruit & 48 & 87.3 & 7.01 & 4.398 & 1.00 & 20.00 \\
Rubber & 46 & 83.6 & 22.33 & 15.218 & 4.00 & 70.00 \\
Vegetables & 23 & 41.8 & 0.32 & 0.206 & 0.125 & 1.00 \\
\hline
\end{tabular}

Data source: Field survey conducted in 2020

\subsection{Ginger cultivation practices}

Table 3 shows that ginger in this area is cultivated by small-scale farmers. Average farm size is about 8 rai (1.3 ha) per household with half of households (52.7\%) growing ginger on about 5-10 rai (0.8-1.6 ha). Most growers cultivate ginger on terrain with a slight slope, at high altitude, and on sandy clay soil. All ginger growers every year search further afield to find new land to avoid rot problems. As it stands, farmers try to find land that was not previously planted with ginger. However, because of land limitations, farmers also cultivate lands that were previously planted with ginger. The general criteria, however, is that the land must have been free from ginger for at least three years. Most of the farmers practice crop rotation. As evident from the survey (Table 3 ), the cycles of rotation varied from 1-15 years with an average of 5.8 years. Almost half of the informants (47.3\%) take 5 years to come back to plant ginger on the same land. Some farmers have a short cycle of rotation because of land paucity. Rice, maize, and cassava are also grown in rotation (Figure 3).
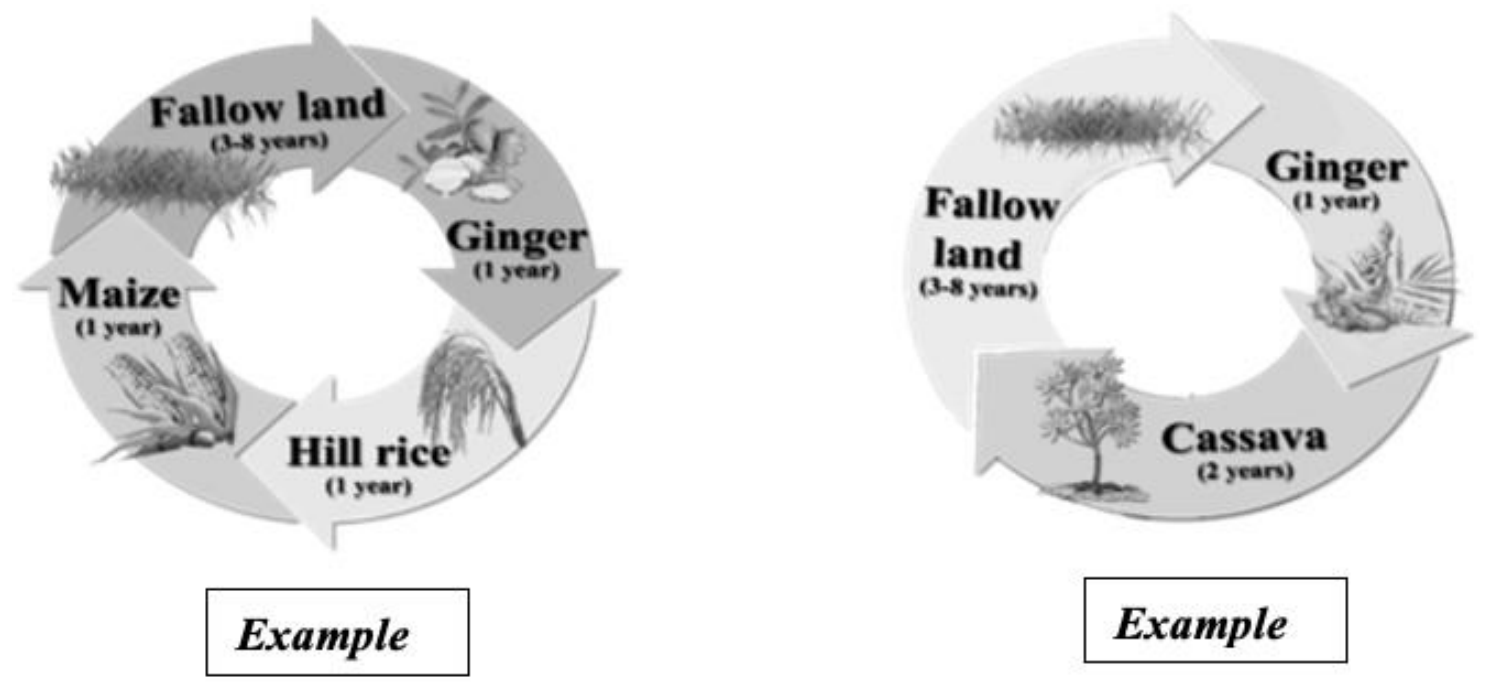

Figure 3 Rotation cycles of land use in ginger cultivation systems

In the fallow land stage, farmers can cut the grass to use in covering the ginger plots. This area does not have much rice straw because there is rarely any area available for rice. Some farmers also believe that using rice straw to cover the files could cause ginger to rot easily. Moreover, the farmers could sell the grass to other ginger farmers at the price of 10 Baht per bundle.

Ginger is propagated by portions of rhizomes, which have at least one good bud. There is only one ginger cultivar that grows in this area which is called Khing Yai (Big ginger) or Khing Yuak (White 
ginger). Most growers (90.9\%) use the rhizomes from their previous crop. The growers usually keep the rhizomes in the ground which they do not harvest until they are ready to grow the following crop (Choenkwan, 2017). Other sources of the rhizomes are neighbors (16.4\%) and merchants (5.5\%) (Table 3). Rhizomes are cut into pieces of the required sizes (usually 2.5 to $5 \mathrm{~cm}$ length) and are immediately planted.

The ginger growing season begins in February and lasts through April for the land preparation and planting stages, depending on rainfall, as listed in Table 5. The rhizomes are planted in one row of beds and chicken manure is used as fertilizer on the bottom layer, which is then covered with soil. Some farmers soak the rhizome with anti-mold solution and root stimulant for about 10-15 minutes before planting. The spacing between rhizomes are around $15-20 \mathrm{~cm}$. Immediately after planting, farmers spray weed control chemicals and beds are covered with mulch, such as grasses of up to 8$10 \mathrm{~cm}$ thickness. Mulching protects seedlings from the sun, prevents weed growth, and keeps soil soft and moist. Usually, growers apply chemical fertilizers 2-4 times per cultivation cycle. The growers are very careful with the ginger during the 2-3 months after planting because these are the highest risk periods for disease. If they can identify the rot in the ginger early on, they will destroy the rotted plants before it infects the entire plot (Choenkwan, 2017). The base of the ginger will be covered by soil to make the rhizome grow larger. If the rhizome is not covered, the resulting rhizome will be small.

For the ginger cultivation process the growers will check the plots every 1-2 weeks to identify potential diseases and pests. The growers take good care of the cleanliness within the plots in terms of both agricultural equipment and the laborers working in the plot. Before entering the ginger plots, farmers will also have to clean themselves and change their shoes to prevent potentially bringing any vectors of disease or infections into the plots.

Most growers use hand labor (94.5\%) and herbicide (89.1\%) for weed management. For disease and pest control, all growers move to other plots, $96.4 \%$ applying chemical agents, $89.1 \%$ soak the rhizomes with anti-mold solution before planting and $67.3 \%$ leave the plots for a period and return for disease and pest control (Table 3).

Ginger can be harvested and sold in two stages, including baby ginger (3-6 months age), and mature gingers (more than 6 months age). Baby ginger is harvested during July to September, whereas mature ginger is harvested from September until January. Some farmers do not harvest the entire crop but leave a portion in situ for seedling purposes until February-March. On average, rhizome yield of baby ginger is about 2.9 ton per rai, whereas rhizome yield of mature ginger is about 2.3 ton per rai (Table 4).

There are two types of selling systems, either to sell as the rhizome or directly as land. Selling rhizomes means that farmers harvest the ginger and sell in accordance with the weight and market price. All growers sell their rhizomes as wholesale, which can be divided into three different channels. First, the growers (10.9\%) can bring the ginger to sell at the markets themselves. The large ginger market is located in Lomsak district, Petchabun province, about 100 kilometers from Plaba. For the second option, growers $(90.9 \%)$ sell to middlemen who live in the village, and lastly, the growers $(47.3 \%)$ opt to sell to middlemen who live outside the village, which mostly come from Lomsak district. Moreover, the price of rhizomes can be graded into three different types (Choenkwan, 2017). The first grade are the highest priced yields, which consists of rhizomes that are large and have clear skin (no damage to the peel). The second grade consists of the rhizomes that are large but appear to have some damage to the peel. The third grade are those of the lowest quality in size and appearance. This type gets the lowest price.

Selling as land means the farmers sells all the production process to the middlemen. The middlemen then pay the farmer according to the size of the land and considers the production costs that the middlemen predict. This requires the middlemen to organize and conduct the harvest. The farmers usually like to sell their products as land because they can save time and reduce hiring costs for harvesting (Chonekwan, 2017). Baby ginger is usually sold as rhizomes, whereas mature ginger 
is sold as both rhizomes and land. An average price of baby ginger is about 18.65 Baht and an average price of mature ginger is about 26.1 Baht.

Table 3. Distribution of informants according to their practices on ginger cultivation $(n=55)$

\begin{tabular}{|c|c|c|}
\hline Characteristics & Frequency & Percentage \\
\hline \multicolumn{3}{|l|}{ Ginger farm size in 2020 (rai) } \\
\hline less than 5 & 19 & 34.5 \\
\hline $5.01-10$ & 29 & 52.7 \\
\hline more than 10 & 7 & 12.7 \\
\hline \multicolumn{3}{|l|}{$\min , 1, \max 25$, mean 8.10, S.D. 4.914} \\
\hline \multicolumn{3}{|l|}{ Rotation period (years) } \\
\hline less than 5 & 12 & 21.8 \\
\hline 5 & 26 & 47.3 \\
\hline more than 5 & 17 & 30.9 \\
\hline $\min 1, \max 15$, mean 5.76, S.D. 2.728 & & \\
\hline \multicolumn{3}{|l|}{ Sources of rhizomes (multiple choices) } \\
\hline previous crop & 50 & 90.9 \\
\hline neighbors & 9 & 16.4 \\
\hline merchant & 3 & 5.5 \\
\hline government agencies & 1 & 1.8 \\
\hline \multicolumn{3}{|l|}{ Weed management (multiple choices) } \\
\hline plowing & 22 & 40.0 \\
\hline hand labors & 52 & 94.5 \\
\hline herbicide & 49 & 89.1 \\
\hline \multicolumn{3}{|l|}{ Disease and pest management (multiple choices) } \\
\hline move to other plots & 55 & 100 \\
\hline leave the plots for a period and then move back & 37 & 67.3 \\
\hline soke the rhizome with anti-mold solution before planting & 49 & 89.1 \\
\hline applying chemical agents & 53 & 96.4 \\
\hline \multicolumn{3}{|l|}{ Harvesting management } \\
\hline own labors & 14 & 25.5 \\
\hline hired labors & 1 & 1.8 \\
\hline both own and hired labors & 40 & 72.7 \\
\hline \multicolumn{3}{|l|}{ Marketing channels (multiple choices) } \\
\hline Sell as wholesale at the market themselves & 6 & 10.9 \\
\hline Sell as wholesale to middlemen who lives in the village & 50 & 90.9 \\
\hline Sell as wholesale to middlemen who lives outside the village & 26 & 47.3 \\
\hline \multicolumn{3}{|l|}{ Production cost in 2019 (Baht) } \\
\hline less than 50,000 & 16 & 29.1 \\
\hline $50,000-100,000$ & 28 & 50.9 \\
\hline more than 100,000 & 11 & 20.0 \\
\hline $\min 5,000, \max 400,000$, mean $88,945.45$, S.D. 67284.751 & & \\
\hline \multicolumn{3}{|l|}{ Income in 2019 (Baht) } \\
\hline less than 100,000 & 17 & 30.9 \\
\hline $100,000-150,000$ & 20 & 36.4 \\
\hline more than 150,000 & 18 & 32.7 \\
\hline $\min 20,000, \max 900,000$, mean $176,000.00$, S.D. 185775.153 & & \\
\hline \multicolumn{3}{|l|}{ Loss or Profit in 2019} \\
\hline loss & 8 & 14.5 \\
\hline Balance & 6 & 10.9 \\
\hline Profit & 41 & 74.5 \\
\hline
\end{tabular}

Data source: Field survey conducted in 2020

Farmers will evaluate their products and then decide what type of rhizomes they will sell. If production quality is good, they will sell it as the first or second grade. If the quality is poor, they will 
combine the stock and sell it as the third grade for a lower price. The ginger price fluctuates every day. Farmers will evaluate the price of ginger from the buyer. If the price is acceptable, they will harvest. If the price is unacceptable, they will not harvest the ginger until they can justify an acceptable price. Ginger will be sold immediately after harvest.

Ginger requires high investment costs, especially among new growers. It requires several thousand Baht for the initial investment, including the cost of the rhizomes, chicken manure, land preparation, and land rent. From the survey, in the production year of 2019, the production costs varied from 5,000 Baht to 400,000 Baht depending on the farm sizes, whereby half of them (50.9\%) invested about 50,000 - 100,000 Baht (Table 3). Moreover, growing ginger also risks price fluctuations and the potential for rot. Therefore, according to one farmer, it would be difficult for new growers to enter the market. Ginger also requires high labor inputs, but this area usually does not have this problem because migrant labor is readily available from neighboring Laos.

Table 4. Characteristics of baby ginger rhizome and mature ginger rhizome

\begin{tabular}{lll}
\hline \multicolumn{1}{c}{ Characteristics } & Baby ginger rhizome & Mature ginger rhizome \\
\hline Farm size & & \\
Mean/SD & $4.86 / 2.956$ & $3.68 / 3.137$ \\
$\quad$ Max/Min & $15.00 / 0.25$ & $15.00 / 0.50$ \\
Harvesting months & July-September & September-February \\
Ages & & \\
$\quad$ Mean/SD & $4.35 / 0.645$ & $8.72 / 1.182$ \\
$\quad$ Max/Min & $6 / 3$ & $11 / 6$ \\
Production (Kg) & & \\
$\quad$ Mean/SD & $14,747.27 / 13805.392$ & $10,312.50 / 15621.039$ \\
Max/Min & $70,000 / 2000$ & $90,000,200$ \\
Yield (Kg/Rai) & & \\
$\quad$ Mean/SD & $2,942.68 / 1853.518$ & $2,333.65 / 1,516.483$ \\
Max/Min & $10,000 / 750$ & $7,000 / 200$ \\
Price (Baht) & & \\
Mean/SD & $18.65 / 2.188$ & $26.21 / 6.159$ \\
Max/Min & $20 / 10$ & $38 / 15$ \\
\hline
\end{tabular}

Data source: Field survey conducted in 2020

Table 5. Calendar of ginger cultivation practices in Plaba sub-district

\begin{tabular}{|c|c|c|c|c|c|c|c|c|c|c|c|c|}
\hline Activity & Jan & Feb & Mar & Apr & May & Jun & Jul & Aug & Sep & Oct & Nov & Dec \\
\hline Land preparation & & $\leftarrow$ & & $\Rightarrow$ & & & & & & & & \\
\hline Planting & & $\leftarrow$ & & & & & & & & & & \\
\hline Fertilizing & & $\leftarrow$ & & & & & & & & & & \\
\hline Weeding & & $\leftarrow$ & & & & & & & & & & \\
\hline Covering up & & & & & & $\leftarrow$ & & & & & & \\
\hline Harvesting & wire & ger rh & & & & & Baby & & & & & \\
\hline
\end{tabular}

Data source: Field survey conducted in 2020

Growers are getting gross returns at somewhere between 20,000 - 900,000 Baht/rai. Gross income varies from one grower to another because of different farm sizes. As per the survey, in the production year of 2019, there were 41 growers (74.5\%) that earn profits and, 6 growers $(10.9 \%)$ 
made back their overall balance, but there were also 8 growers $(14.5 \%)$ that had a loss from ginger production (Table 3)

\subsection{Impacts of COVID-19 outbreak on ginger production and its coping strategies}

The COVID-19 crisis began in Thailand in January 2020 with the peak of the crisis unfolding from March to June, in which the government announced heavy restrictions on travel and mobility, which is the start of the growing season for ginger. In regard to the survey, the COVID-19 pandemic has affected ginger production. Key findings are as follows:

\subsubsection{Increased price of rhizome seeds}

The survey indicated that $25.4 \%$ of farmers reported that the price of rhizome seed has increased due to the COVID-19 outbreak and has made travel and transportation more difficult. Middlemen who sell the rhizome seed were unable to enter the area resulting in the price of rhizome seed to increase. This result coincides with previous studies that explain COVID-19 restriction measures have impacted the supply of farm inputs, such as seed and fertilizer, as well as access to extension services. These disruptions adversely affected bean production among rural poor and marginalized groups, cutting them off from output markets (Siche, 2020). In eastern and southern Africa, COVID-19 affected seed distribution to farmers (Nchanji et al., 2021). This effect created disruptions of bean seed systems, which is the crucial crop grown to improve incomes, food, and nutrition security, also influencing health outcomes of resource-poor smallholder households (Nassary et.al, 2020).

Coping strategies: Most farmers usually use their own rhizome seed for the next crop. During this COVID-19 outbreak, they will keep more rhizome seeds for their own use. The farmers who were unable to keep the rhizome seed for their own uses bought the rhizome seed from their neighbors. Some farmers reduced farm sizes for ginger production because of the high price of the rhizome seed.

\subsubsection{Increased labor costs}

Ginger production requires high labor inputs especially skilled laborers, which requires specific skills in each step of the production process, such as, planting, harvesting and grading rhizomes. These steps cannot use machinery. Usually, this area does not have a problem with the lack of these types of labor because the migrant labor force is readily available from neighboring Laos. However, during the COVID-19 situation, $60 \%$ of farmers reported that they were affected by labor shortages due to international travel restrictions. Laborers from Laos could not travel to Thailand resulting in labor shortage and increased cost of available laborers in this area from 300 Baht per day to 500 Baht per day. This problem was also found in other places. In India, for example, the national lockdown at the end of March 2020 resulted in many workers, including migrants across economic sectors returning to their home regions and resulting in decreased labor availability in agricultural production in certain areas (Balwinder-Singh et al., 2020). Meanwhile, Kumar et al. (2021) indicates that as labor were forced to migrate back to their homes, the availability of labor for carrying out farm operations has dramatically increased in some local communities. At those locations, daily wages at the village level have dropped by as much as $15-20 \%$. Moreover, decreasing labor availability in the periods for harvesting crops, especially horticulture crops which require skilled labor has jeopardized the products. Most of the crops ripened in orchards without harvesting them resulting in quality deterioration. Some farmers were throwing their produce on roads and dumping in compost pits (Joshi et al., 2019). Sengupta and Felman (2020) indicate that labor shortages during harvest time resulted in falling production curves. In South Asia, transportation limitations on migration have created a problem of labor shortage (FAO 2020a), particularly for the harvest of South Asia's winter season crops including rice, wheat, and horticultural crops (ICRISAT, 2020).

Coping strategies: some growers tried to use their own labor to make up for these conditions. Some growers who have large farms and really need the labor have hired at a higher price. There 
are available Thai labor at lower wages in neighboring villages, but farmers could not hire them because they do not have the skill or experience in ginger production.

\subsubsection{Increased input costs}

During the COVID-19 situation, travel has become more difficult causing the transportation of production inputs such as chemical fertilizers, pesticides, and chicken manure to this area to be limited. The survey indicated that $67.3 \%$ of farmers reported that it is difficult for them to afford inputs as a result of increased cost of these production inputs, especially chicken manure, which usually requires trucks to bring the chicken manure from the farms in other areas to the community. The COVID-19 outbreak, therefore, rarely has allowed for trucks to bring chicken manure to the region, resulting in prices going up. Blank (2020) reports that transport restrictions in Zimbabwe, South Sudan, and Sudan make it particularly difficult for suppliers to get inputs such as seeds, fertilizers, crop protection products, equipment, and animal feed to rural farmers in time for planting season, disrupting production of staples such as rice, maize, and vegetables. These problems, fertilizer shortages during harvesting time have heavily affected production curves (Sengupta and Felman, 2020). In eastern and southern Africa, Nchanji et al. (2021) indicates that government restrictions impacted the availability and cost of farm inputs and labor for bean production. In Bangladesh, logistical constraints also affect feed supplies of aquaculture, poultry, and livestock production (FAO, 2020b). In Nepal, the lockdown has adversely affected food availability through production, as well as impacting trade and distribution as the supply chains of inputs and farm products were disrupted (Adhikari et al., 2021). Zankan, J.A.A. et al. (2020) also found that the negative effects of COVID-19 on agriculture in Kaduna State in Nigeria increased seedling price, input, and farm labor cost.

Coping strategies: Some farmers reduced their farm cultivation areas. However, inputs are still required. Therefore, they need to buy these inputs at a higher price.

\subsubsection{Time spent in activities in the ginger plot was decreased}

Farmers planting ginger areas were sometimes located in different villages or sub-districts far away from their homes. During this COVID-19 situation, travelling to the ginger field became more difficult because it delayed each community in having a screen checkpoint for COVID-19 infected people who passed through the community. As a result, farmers reduced their time working in their ginger fields. For example, usually they can work in the ginger field 8 hours per day but in this situation, they can work only 4-5 hours per day.

Coping strategies: They spent several more days working in the ginger fields. For example, usually they can finish their works on weed management in 7 days but this time they had to take 10-12 days to finish this task.

\subsubsection{Increased price of rhizome}

The survey reported that $72.8 \%$ of farmers stated that the price of ginger production is higher compared to the previous year. Some farmers reduced the area for growing ginger when COVID-19 began to spread around the period of the growing season. This is because they were worried that they would not be able to sell their products because of the lack of markets. However, surprisingly, the price of ginger production has increased, which also provided the opportunity to result in higher profits to farmers. One farmer indicated that last year she earned about 30,000 Baht, but this year amid COVID-19 she earned about 40,000 Baht for 1 rai of ginger. The price of ginger has also increased in many countries such as in Indonesia, Kazakhstan, Bashkiria, Russia, Australia, and China (Ayipey, 2020). The increase in the prices of ginger could be influenced by two factors. Firstly, is likely due to limited supply of ginger in the main export countries since the lockdown. Secondly, there is also a growing belief that ginger can be used as an antioxidant to prevent a person from being infected with the coronavirus. Even though this assertion has been refuted by the WHO, particularly that traditional remedies such as ginger consumption do not have a scientific proof to 
combat or cure COVID-19, this has not stopped individuals from hoarding ginger or employing their traditional herbal techniques in combatting the virus as they wait for the vaccine (Ayipey, 2020).

\subsection{Impacts of COVID-19 outbreaks on ginger grower households and livelihoods, and their coping strategies}

Generally, the COVID-19 pandemic has not, as yet, vastly impacted ginger grower households. However, there are some impacts on certain households. Regarding the survey, $94.5 \%$ of farmers reported that their household income has decreased because of the travel ban, the social distancing policy, and fear of infection. They cannot sell their agricultural products, especially dragon fruits. Dragon fruit is one of important agricultural products of ginger grower households. Usually, they deliver dragon fruit products to sell at the market themselves, which are located in other provinces such as Udon Thani and Roi Et provinces. During the COVID-outbreak, they were unable to deliver the products themselves, and therefore they had to sell their products to middlemen instead, which resulted in a near $50 \%$ decrease of their income.

Moreover, some farmers expressed a loss of income from selling lottery. Selling lottery is an important non-farm activity and income source of these households. To do this job, they must travel to other provinces all over the country and stay there for 7-10 days to sell lotteries. Income earning from this job is about 10,000-15,000 Baht per month. During the COVID outbreak, the government announced the suspension of lottery sales for 2 months, which resulted in them losing their income.

However, the COVID-19 outbreak does not have overall effects on food supply because they reported having adequate supplies among their households of chicken and vegetables. Moreover, they also gathered food from the forest such as bamboo shoots, vegetables, and mushrooms. However, $92.7 \%$ of farmers reported that their household expenses have increased because they need to purchase cleaning products and prevent germs for use in the household, such as hand sanitizer and face mask, which was very expensive during the COVID-19 outbreak. Finally, most farmers expressed that they were afraid to be in crowded groups. Thus, they decided not to participate in community events and ceremonies such as Buddhist Ordination and weddings. They mostly stayed home, socializing less with their neighbors.

\section{Conclusions}

The effects of COVID-19 on ginger production and ginger farmer households are substantial, particularly due to the lockdown and transportation restrictions. Figure 4 presented the flow chart of COVID-19 impact pathways affecting ginger production systems and ginger farmer households. The mobility restrictions affected input supply chains, such as fertilizer and rhizome seeds. The flow of international labor was constrained, affecting skilled labor shortages in ginger production areas, and consequently, increasing labor cost. Moreover, skilled labor shortages also affected ginger production quality. However, COVID-19 showed the positive impacts on ginger production systems. Ginger prices were higher than previous years, which have benefitted ginger farmers.

The lock down and transportation restrictions also affected ginger farmer households. Some households lost substantial income from other crops such as dragon fruits and non-agricultural sources such as selling lottery. This highlights the importance of crop commodities to examine the relationships between crop production systems. In addition, remittances are not a main source of income for ginger farmers. Therefore, business closures do not have significant effects on ginger farmer households. Moreoverthe COVID-19 does not affects food security among those surveyed in this study because they do not depend on markets for their food. The food was consumed at home as part of their local growing systems and the use of forest products. Adhikari et al. (2021) indicated that in Nepal, subsistence farming households are resilient in the crisis of COVID-19 as they depend on local inputs such as local indigenous seeds, compost, and family, and community labor exchange. They did not depend as much on markets for products consumed locally. This type of household also has the potential to absorb people who migrated back to the village from cities because of COVID- 
19 (UNDP, 2020). Adhikari et al. (2021) indicated that strong community relations play an important role to help vulnerable people who are affected from this pandemic, and a strong community has the systems to share resources, such as seeds and labor, which would be an effective way to overcome transportation disruptions on key supplies.

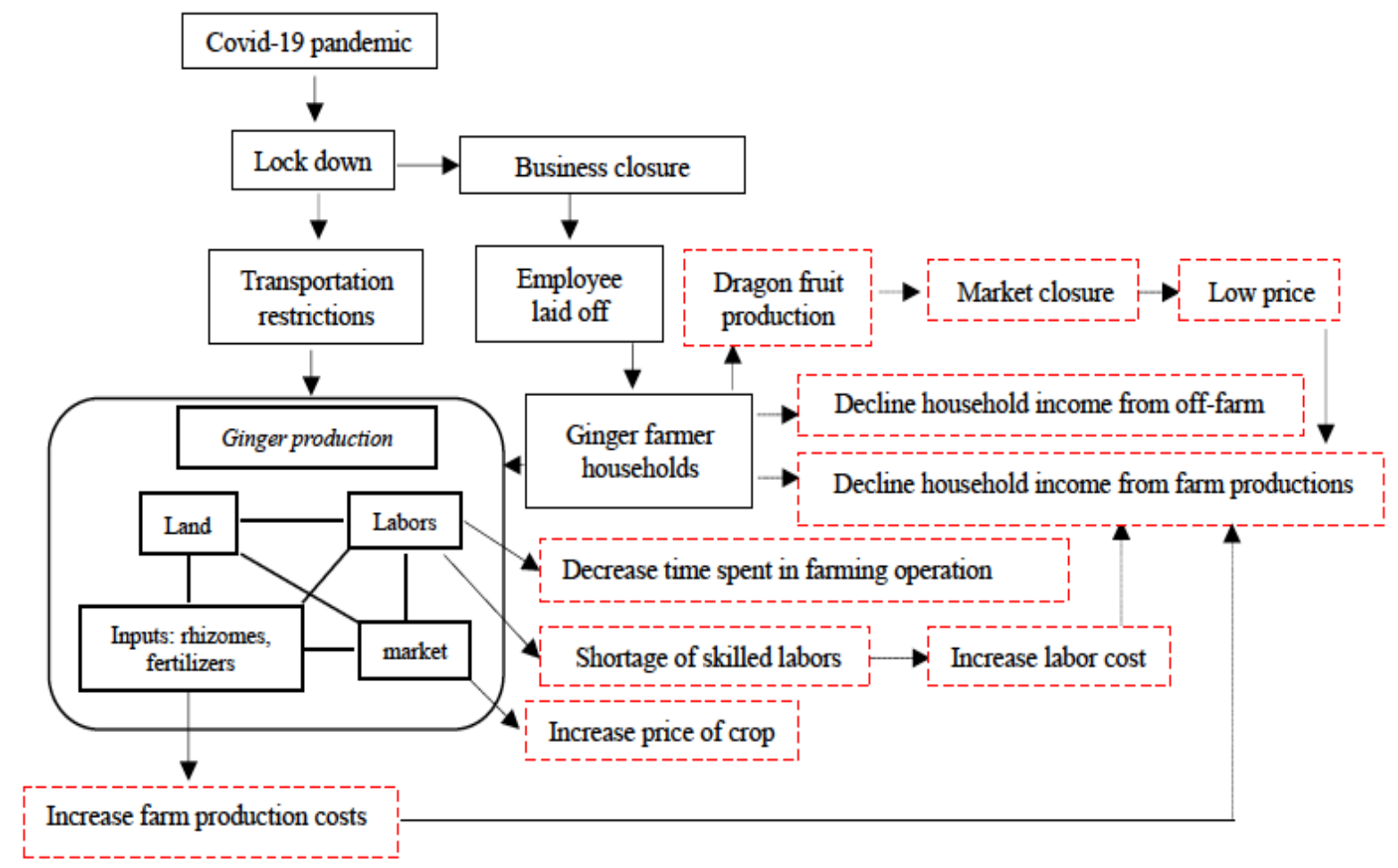

Figure 4. Flow chart of COVID-19 impact pathways affecting ginger production system and ginger farmers' households in Plaba sub-district

The crisis of COVID-19 pandemic has made us realize the problem when we depend on others. In Nepal, a policy debate on the necessity to become self-sufficient in food production has been raised (Adhikari, 2020; Chaurasia et al., 2020). However, promoting the country to become a selfsufficient production system are quite extreme. In Thailand, sufficiency economy approach has been promoted for decades, but it has rarely shown the success. In Plaba sub-district, although ginger and dragon fruit are main commercial crops for these farmer households which are affected from the outbreak and their important non-agricultural income source are disrupted resulting in their household incomes are decreased. It has been shown that these ginger farmers are somewhat resilient in the face of COVID-19 as they are not much depending on market for their own food. The problem of food security in this area is not exist.

Conclusively, Plaba ginger farmers are in semi-commercial farming households which can survive with the crisis because they can produce food for their own consumption. Although, one crop failed they can have other crops to live on. Therefore, promoting farmers to produce their own food and diversify their commercial crop would be a good strategy for farmers to survive the crisis. Thus, the government agencies who work in community development or agricultural development should be more focused on this issue.

\section{Acknowledgment}

This paper is based on the first author's preliminary thesis research in the Program on Agricultural Extension and Development, Faculty of Agriculture, Khon Kaen University. This research was funded by 
Graduate School, Khon Kaen University for supporting Lecturer to Admit High Potential Student to Study and Research on His Expert Program Year 2020 (631T102).

Conflicts of Interest: The authors declare no conflict of interest

\section{References}

Abhishek, B., Vaibhav, G., Puneet, K., Manu, Kishore, A., Kumar, R., Sharma, A., \& Verma, S. (2020). India's food system in the time of COVID-19. Economic and Political Weekly, 55(15), 12-14. Retrieved from https://www.epw.in/journal/2020/15/commentary/indias-food-system-timeCOVID-19.html.

Adhikari, J. (2020). A future in farming. Retrieved from https://www.recordnepal.com/perspective/a-future-in-farming/

Adhikari, J., Timsina, J., Khadka, S.R., \& Ghale, Y. (2021). COVID-19 impacts on agriculture and food systems in Nepal: Implications for SDGs. Agricultural Systems, 186, 1-7. https://doi.org/10.1016/j.agsy.2020.102990

Amjath-Babu, T.S., Krupnik, T.J., Thilsted, S.H., \& Mcdonald A.J. (2020). Key indicators for monitoring food system disruptions caused by the COVID-19 pandemic: Insights from Bangladesh towards effective response. Food Security, 12, 761-768. https://doi.org/10.1007/s12571-020-01083-2

Asia-Pacific Farmers Program. (2020). Southeast Asia Farmers' Organizations Response to COVID19. Retrieved from http://www.asiapacificfarmersforum.net/southeast-asia-farmersorganization-covid19-response/

Ayipey, P. (2020). Impact of COVID-19 on ginger export, a root crop as traditional remedy for COVID19. Journal of Basic and Applied Research in Biomedicine, 6(1), 25-31.

Balwinder-Singh, Shirsath, P.B., Jat, M.L., McDonald, A.J., Srivastava, A.K., Craufurd, P., Rana, D.S., Singh, A.K., Chaudhari, S.K., Sharma, P.C., Singh, R., Jat, H.S., Sidhu, H.S. Gerard, B., \& Braun, H. (2020). Agricultural labor, Covid-19, and potential implications for food security and air quality in the breadbasket of India. Agricultural Systems, 185, 1-8. https://doi.org/10.1016/j.agsy.2020.102954

Bc, L. (2019). Ginger production. Retrieved from https://www.researchgate.net/publication/334587472_Ginger_Production

Blank, J. (2020). Economic impact of COVID-19: Protecting Africa's food systems from farm to fork. Retrieved from https://www.brookings.edu/blog/africa-in-focus/2020/06/19/economicimpact-of-covid-19-protecting-africas-food-systems-from-farm-to-fork/

Chaurasia, J., Parajuli, M., \& Khadka, G.B. (2020). Changing approach to food self-sufficiency on the scenario of the pandemic "COVID-19". Environment and Ecosystem Science, 4 (1), 43-46. http://doi.org/10.26480/ees.01.2020.43.46

Choenkwan, S. (2017). Mysterious ginger: Enclaves of a boom crop in Thailand. Forest and Society, 1(2), 144-153. https://doi.org/10.24259/fs.v1i2.2117

Choenkwan, S., Fox, J.M., \& Rambo A.T. (2014). Agriculture in the Mountains of Northeastern Thailand: Current Situation and Prospects for Development. Mountain Research and Development, 34(2), 95-106. https://doi.org/10.1659/MRDJOURNAL-D-13-00121.1

Department of Agriculture Extension. (2019). Ginger : production in 2018. (in Thai) Retrieved from http://www.agriinfo.doae.go.th/year62/plant/rortor/veget/13.pdf

Department of Agriculture Extension. (2020). Summary of important agricultural and cooperative statistics. (in Thai) Retrieved from https://www.opsmoac.go.th/nakhonsithammarat-dwl-files421191791137

FAO. (2020a). Migrant workers and the COVID-19 pandemic. Retrieved from http://www.fao.org/3/ca8559en/CA8559EN.pdf.

FAO. (2020b). Rapid assessment of food and nutrition security in the context of COVID-19 in Bangladesh. Retrieved from 
https://fscluster.org/sites/default/files/documents/fao_bangladesh_covid19_rapid_assessment_report_09-05-2020_final13may2020.pdf.

FAOSTAT. (2020a). Countries by commodity Ginger 2019. Retrieved from http://www.fao.org/faostat/en/\#rankings/countries_by_commodity_exports

FAOSTAT. (2020b). Production quantities of Ginger by country 2019. Retrieved from http://www.fao.org/faostat/en/\#data/QC/visualize

Geta, E. \& Kifle, A. (2011). Production, processing, and marketing of ginger in Southern Ethiopia. Journal of Horticulture and Forestry, 3(7), 207-213. Retrieved from https://doi.org/10.5897/JHF.9000093

ICRISAT. (2020). Containing covid19 impacts on Indian agriculture. Retrieved from https://www.icrisat.org/containing-covid19-impacts-on-indian-agriculture/.

Joshi, P., Kulkarni, U., Munje, S., \& Kulkarni S. (2019). Impact of Covid-19 pandemic on Indian fruits and vegetables export, postharvest management supply chain and future strategies. AgricInTERNATIONAL, 6(2), 4-8. https://doi.org/10.5958/2454-8634.2019.00015.9

Kumar, P., Singh, S.S., Pandey, A.K., Singh, R.K., Srivastava, P.K., Kumar, M., Dubey, S.K., Sah, U., Nandan, R., Singh S.K., Agrawal, P., Kushwaha, A., Rani, M, Biswas, J.K., \& Drews, M. (2021). Multi-level impacts of the COVID-19 lockdown on agricultural systems in India: the case of Uttar Pradesh. Agricultural Systems, 187, 1-10. Retrieved from https://doi.org/10.1016/j.agsy.2020.103027

Local Act. (2020). Impact of COVID-19 on the agricultural sector, proposals and farmer adaptation. Retrieved from https://www.landactionthai.org/2012-05-18-03-24-45/article/item/2393-192.html. (in Thai)

Münster, D. (2015). "Ginger is a gamble" Crop booms, rural uncertainty, and the neoliberalization of agriculture in South India. Facaal-Journal of Global and Historical Anthropology, 71, 100-113. https://doi.org/10.3167/fcl.2015.710109

Nassary, E.K., Baijukya, F., \& Ndakidemi, P.A. (2020). Assessing the productivity of common bean in intercrop with maize across agro-ecological zones of smallholder farms in the northern highlands of Tanzania. Agriculture, 10, 117 Retrieved from https://doi.org/10.3390/agriculture10040117

Nchanji, E.B., Lutomia, C.K., Chirwa, R., Templer, N., Rubyogo, J.C., \& Onyango, P. (2021). Immediate impacts of Covid-19 pandemic on bean value chain in selected counties in sub-Saharan Africa. Agricultural systems, 188, 1-13. Retrieved from https://doi.org/10.1016/j.agsy.2020.103034

Office of Soil Resource Survey and Research. (2008). Land Use Zone. Bangkok: Department of land development. (in Thai)

Plaba Tambon Administrative Organization. (2019). Development plan of Plaba sub-district during 2015-2017. Loei province: Plaba Tambon Administrative Organization. (in Thai) Retrieved from http://plaba.endutot.com/upload-files/uploadfile/25/20181105100909.pdf.

Sengupta, R. \& Felman, J. (2020). RBI vs. COVID-19: understanding the announcements of March 27. Retrieved from theleapjournal.org

Siche, R., (2020). What is the impact of COVID-19 disease on agriculture?. Scientia Agropecuaria, 11(1), 3-6. Retrieved from http://dx.doi.org/10.17268/sci.agropecu.2020.01.00

Thailand law online. (2016). Land laws, land title documents. Retrieved from http://www.thailandlawonline.com/article-older-archive/land-title-deeds-land-documents-inthailand

Tungkanjanapas and Chotiwattanakun. (2020). The private sector, with the COVID-19 monsoon: the vulnerability of the household sector and amelioration measures, no one left behind. Retrieved from

https://www.bot.or.th/Thai/ResearchAndPublications/articles/Pages/Article_12May2020.asp $x \#$ (in Thai) 
UNDP. (2020). Rapid Assessment of Socio Economic Impact of COVID19 in Nepal. Retrieved from https://www.np.undp.org/content/nepal/en/home/library/rapid-assessment-of-socioeconomic-impact.html

Zankan, J.A.A., Abdul, H.A., Abdul, H.A., \& Shat, A.T. (2020). African Journal of Agricultural and Food. Effects of COVID-19 on Agriculture in southern Kaduna state of Nigeria. African Journal of Agriculture and Food, 3(4), 63-78. Retrieved from https://abjournals.org/ajafs/wpcontent/uploads/sites/16/journal/published_paper/volume-3/issue-4/AJAFS_DBTUEBLU.pdf 